\title{
A vakvezetőkutya és az eszközhasználat, mint a látássérült személyek önértékelését befolyásoló tényezők
}

\author{
MONI IMOLA \\ moni imola@yahoo.com
}

\begin{abstract}
ABSZTRAKT
Háttér és célok: A globális önértékelés általában a jóllét és a mentális egészség meghatározó eleme (Rosenberg, Schooler, Schoenback, \& Rosenberg, 1995), amely a gyógypedagógiai rehabilitációs munka eredményességének egyik mutatója lehet. A látássérült személyek önértékelését vizsgáló tanulmányokat tekintve (Huurre, Komulainen \& Aro, 1999; Cardinali \& D'Allura, 2001; Papadopoulos, Montgomery \& Chronopoulou, 2013), a kutatók között nincs egyetértés arra vonatkozóan, hogy a látássérült személyeknek alacsonyabb lenne az önértékelésük, mint látó társaiknak. Célunk az volt, hogy a Magyarországon éló látássérült személyek globális önértékelését megvizsgáljuk az elsődleges, leggyakrabban alkalmazott közlekedési szokások, formák mentén.

Módszerek: A vizsgálatunkba 93 felnôtt látássérült személyt vontunk be (58 nő és 35 férfi, átlag életkoruk 42 év). Az elsődleges közlekedési formák/szokások szerint csoportokra osztottuk a résztvevôket - vakvezető kutyával közlekedők (n=13), fehér bottal közlekedők ( $\mathrm{n}=36$ ), látóvezetôvel közlekedők ( $\mathrm{n}=15)$, segédeszköz nélkül önállóan közlekedő, látásmaradvánnyal rendelkező látássérült személyek ( $\mathrm{n}=27)$. A résztvevôk a Rosenberg Önértékelés Skálát töltötték ki online formában. Az eredményeket a már meghatározott csoportok között hasonlítottuk össze. A vizsgálat során a csoportok közötti különbségeket mértük.

Eredmények: Megállapíthattuk, hogy a csoportok között nincs szignifikáns különbség (p>,05) az önértékelés tekintetében.

Követkęৃtetések: A jelen kutatásban résztvevổ látássérült személyek önértékelését közvetlenül nem befolyásolja az, hogy az adott személy a felsorolt közlekedési formák közül melyiket használja előszeretettel.
\end{abstract}

Kulcsszavak: önértékelés, látássérülés, közlekedés, fehér bot, vakvezetőkutya

\section{HÁTTÉR ÉS CÉLOK Bevezetés}

A vakvezetőkutyával és segédeszközzel történő közlekedés a látássérült felnőttek rehabilitációjának meghatározó elemei. A tanulmány célja kevéssé vizsgált tényezők együttese mentén feltérképezni a Magyarországon élő látássérült felnőttek önértékelését. A látássérült személyek által használt elsődleges közlekedési módokat, formákat tanulmányozva, majd azokat elhatárolva egymástól vizsgáljuk meg a látássérült felnőttek globális önértékelését.

A tanulmányhoz köthető fontosabb témák, mint a látássérült személyek önértékelése, a látássérült személyek tájékozódása és közlekedése kapcsán kevés kutatás született, és azok főleg külföldi, angol nyelvű szakirodalmakban fellelhetők. 


\section{Az önértékelés meghatározása}

Az önértékelés az emberi viselkedés fontos meghatározója (Marsh \& Shavelson, 1985). Leginkább a hierarchikus modelleken keresztül lehet megérteni, mivel az egyének az önértékelés különféle szintjeit mutathatják be, attól függően, hogy éppen melyik területen fejeződik ki (pl. tanulmányi, társadalmi, sport), és hogy az egyének milyen fontosságot tulajdonítanak az adott területnek (Guerra \& Bradshaw, 2008).

Ha az önértékelést hierarchikus rendszerként képzeljük el, akkor az egység csúcsán a globális önértékelés helyezkedik el, és ezt pedig az egész rendszer általános értékelésének tekintjük (például Harter, 2006; Marsh, 1990). A globális önértékelés általában a jóllét és a mentális egészség meghatározó eleme (Rosenberg, Schooler, Schoenback, \& Rosenberg, 1995), ami a gyógypedagógiai rehabilitációs munka eredményességének egyik mutatója is lehet. Az alacsony globális önértékelés a depresszióval és a szorongással függ össze, míg a magas önértékelés az elégedettséghez és a boldogsághoz kapcsolódik (Harter, 1999).

A magas globális önértékelés kialakításához és fenntartásához fontos, hogy adaptív módon meg tudjunk birkózni a rólunk szóló negatív információkkal (Baumeister, 1993). Mivel a pozitív vélemények növelhetik az önértékelést (Baumeister, Campbell, Krueger, \& Vohs, 2003), lényeges, hogy azokat is megfelelően kezeljük.

A klasszikus önértékelési kutatások kétféle elméleti megközelítést határoznak meg az önértékelés alapvető természetéről. Az intraperszonális elméletek azt feltételezik, hogy az önértékelés nem más, mint a személy önmagára vonatkozó értékelése. Az interperszonális elméletek viszont azt állítják, hogy az egyént nagymértékben befolyásolja, hogy mások hogyan ítélik meg őt. Ez azt jelenti, hogy az önértékelése, magáról alkotott képe kialakításához információt szolgáltatnak mások, vagyis abba beépül a környezet rá vonatkozó megítélése is. A szimbolikus interakcionista megközelítések azt hangsúlyozzák, hogy az önértékelésre a társadalom is befolyást gyakorol (MacDonald, Saltzman, \& Leary, 2003).

Egy-egy populációnál az interperszonális megközelítés sokkal hangsúlyosabb, mint például a látássérült személyek esetében, hiszen a látássérülésből fakadó sajátosságok miatt a társadalmi befolyás fontos tényezőként jelenhet meg az önértékelés tekintetében. Bizonyítást nyert, hogy a látásvesztés pszichológiai következményekkel jár, beleértve a társadalmi elszigeteltséget és a társadalmi interakciók csökkenését. Ezek a tényezôk befolyással lehetnek a személy önértékelésére (Branch, Horowitz, \& Carr, 1989). Azonban érdemes fordított nézőpontból is megvizsgálni a kérdést. Az emberek globális önértékelésében nagy különbségek mutatkoznak, amelyek fontos társadalmi és érzelmi következményekkel járnak. Pontosabban, az alacsony önértékelésủ egyének nagyobb érzékenységet mutatnak a társadalom felől érkező visszajelzések iránt (például elfogadás vagy elutasítás jelei), mint a magas önértékeléssel rendelkező emberek (Richter \& Ridout, 2011).

Fontos kiemelni, hogy az emberek a legtöbb helyzetben pozitívan vélekednek magukról, mégis nagy egyéni különbségek mutatkoznak a globális önértékelés terén (Rosenberg, 1965).

\section{Látássérïlt személyek önértékelése}

Viszonylag kevés kutatás született a látássérült felnőttek önértékeléséről. A látásvesztés egyénenként eltérő pszichológiai következményekkel jár, beleértve a depressziót, a társadalmi 
elszigeteltséget, az önértékelés csökkent érzetét, az érzelmi biztonság és a társadalmi interakciók csökkenését (Branch, Horowitz, \& Carr, 1989). Arra vonatkozóan, hogy a látássérült személyeknek alacsonyabb lenne az önértékelésük, mint látó társaiknak, a kutatók között nincs egyetértés (Huurre, Komulainen, \& Aro, 1999). Cardinali és D'Allura (2001) felmérése alapján látássérült fiatal felnőttek átlagos önértékelési szinttel rendelkeznek. Egy később megjelent kutatásban azonban azt bizonyították, hogy a látó felnőttek önértékelése magasabb, mint a vak és gyengénlátó személyeké (Papadopoulos, Montgomery, \& Chronopoulou, 2013). Bizonyos sajátosságok mentén vizsgálva a látássérült személyek önértékelését, különbségek mutatkoznak a látó emberekhez viszonyítva. Több, fiatal felnőttek körében végzett kutatás bizonyította, hogy a látássérült lányok magasabb önértékeléssel rendelkeznek, mint a látássérült fiúk (Bowen 2010; Were, Indoshi, \& Yalo, 2010), ugyanakkor két másik, későbbi tanulmány nem talált bizonyítékot arra, hogy a vizsgált személyek neme befolyásolná azok önértékelését (Datta \& Talukdar, 2016; Mishra \& Singh, 2012). Augestad (2017) tanulmányában több kutatást összehasonlítva arra a következtetésre jutott, hogy a látássérült lányok önbecsülése alacsonyabb, mit a látássérült fiúké.

A látássérült személyeknél meghatározó lehet az önértékelés tekintetében a látásvesztés, vagy a látásromlás bekövetkeztének időpontja. Az úgynevezett szerzetten látássérült élő személyek, akiknél serdülő- vagy felnőttkorban jelentkezett a látássérülés, alacsonyabb önértékeléssel rendelkeznek, mint a veleszületetten látássérült személyek (Papadopoulos és mtsai, 2013; Papadopoulos, 2014). Emellett fontos kiemelni, hogy a látássérüléshez való alkalmazkodás viszonylag könnyebb, ha az csecsemő- vagy kisgyermekkorban következik be, nem pedig serdülőkorban vagy felnőttkorban. A szerzetten látássérült személyek esetében a zavart érzelmi állapot mellett (Roy \& MacKay, 2002) nem elhanyagolható tény, hogy a látásromláshoz való alkalmazkodás folyamata hosszú ideig tarthat (Wortman \& Silver, 1989).

Az úgynevezett szociális tükör kulcsfontosságú szerepet tölt be az önértékelés alakulásában. A környezettől érkező túlzott segítségnyújtás azt eredményezi, hogy a látássérült fiatal folyamatosan negatív tükörrel szembesül. A túlzott védés, féltés a mozgásszabadság korlátozása mellett a függetlenségre képtelen ember képét vonja maga után (Pálhegyi, 1981). Tuttle és Tuttle (1984) szerint a függetlenség az egyik legfontosabb tényező a látássérült egyének alkalmazkodásában. Így tehát a negatív szociális tükör káros következményt vonhat maga után, amely kihathat a személy egész életére, életvitelére (Webster \& Roe, 1998).

A látássérült személyek önértékelése kapcsán fontos megemlíteni egy másik tényezőt is, a kontroll dimenziót, másnéven a kontrollhelyet (Locus of control- LOC). Pozitív közvetlen kapcsolat figyelhető meg a belső kontrollhely és a globális önértékelési szint között (Saadat, Ghasemzadeh, Karami, \& Soleimani, 2012).

A kontrollhely azt reprezentálja, hogy egy individum milyen mértékben tulajdonítja a vele történő eseményeket külső vagy belső tényezőknek. A belső kontrolhellyel rendelkezők felelősséget vállalnak saját viselkedésükért, magabiztosabbak és aktívabbak a tervezésben vagy a döntéshozatalban, és készek azt hinni, hogy a siker saját erőfeszítéseikből származik (Webster \& Roe, 1998). Másrészről a külső kontrollhely azt az egyént jellemzi, aki más emberek vagy szituációs változók mentén erősen ellenőrzöttnek tekinti magát (Warren, 1984), és hajlamos a külső erők eseményeire hivatkozni, a problémákat projektálni, és tehetetlennek tekinti magát (Webster \& Roe, 1998).

A kontrollhely szerepet játszik abban, hogy mennyire sikeres az adott személy látássérüléshez való alkalmazkodása (Dodds, 1993). Emellett fontos megemlíteni, hogy azok a látássérült felnőttek, 
akik képesek önállóan tájékozódni/közlekedni, belső kontrolhellyel rendelkeznek. Ez fontos megállapítás, mivel így a kontrollhely fogalmát a tájékozódási és közlekedési képességgel kapcsolatba lehet hozni (Papadopoulos, 2014), így közvetve ugyan, de a látássérült személyek önértékelésével is összefüggésbe hozható.

\section{Látássérült személyek segédeszköz-használata a tájékozódás-közlekedés során}

A látássérült személyek számára készült segédeszközök fő célja a függetlenség és önállóság elérése. Kétségtelen, hogy a látássérült emberek mindennapi életében az önálló és biztonságos mobilitás hiánya az egyik legsúlyosabb akadály (Fallah, Apostolopoulos, Bekris, \& Folmer, 2013). A mobilitással kapcsolatos feladatok megkövetelik a különféle térinformációk (pl. tárgyak mozgása, perspektíva, mélység és térbeli szervezés) kombinálásának képességét, amelyhez leginkább a vizuális csatornán keresztül szerzett információk segítenek hozzá. A látássérült emberek mobilitása olyan tevékenységként is értelmezhető, amely egyesíti a következő képességeket: a tér érzékelését, a tájékozódást, az útkeresést, a navigációt és az akadályok elkerülését (Strumillo, 2010).

A tájékozódás és közlekedés tanítása fontos eleme a gyógypedagógiai rehabilitációs munkának. Már óvodás, kisiskolás kortól oktatják, és célja hogy a látássérült személy önálló közlekedôvé váljon az egyéni sajátosságaihoz mérten (Neal, Bigby, \& Nicholson, 2004; Dávid, Gadó, \& Csákvári, 2008). Az önálló közlekedéshez szükséges egyes alapvető technikák elsajátítása (ilyen például az irányfelvétel, a védőtartások, látóvezetővel való közlekedés technikái és a vezetővonal követése) mellett az érzékszervek és érzékelés fejlesztésére is nagy hangsúlyt kell fektetni. Ezeknek a technikáknak az elsajátítását követően szokták a fehér bot használatának tanítását megkezdeni (Dávid, Gadó, \& Csákvári, 2008).

A fehér bot megalkotása 1950-re tehető, amikor is a Valley Forge kórház első hadnagya és szemésze, dr. Richard Hoover létrehozott egy hosszú és könnyú botot. Erre az eszközre úgy lehet tekinteni, mintha a mutatóujj meghosszabbítása lenne. Segítségével a látássérült személy tapintással, kinesztetikus, haptikus érzékelésen keresztül érzékeli az előtte lévő helyet, felismerve a saját környezetét, az akadályokat, a tereptárgyak elhelyezkedését, és így kialakítva az alsó test védelmét az ütközések ellen. Ez a bot egy könnyü üvegszálas vagy fémcső, melynek hosszúságát az egyén preferenciája határozza meg.

A látássérült személyek többféle lehetőség közül választhatnak, amivel megkönnyíthetik a tájékozódásukat, közlekedésüket. A fehér botot tekintik a legolcsóbbnak és a legbiztonságosabbnak. Azonban csak abban az esetben lehet azt mondani, hogy biztonságos ez a közlekedést segítő eszköz, ha helyesen és rendeltetésszerūen használják (Guimares, Henriques, \& Pereira, 2016).

A technika fejlődésének köszönhetően a fehér bot használata mellett az utóbbi időben többféle, a tájékozódást és közlekedést segítő eszköz jelent meg. Manapság a tudományos közösség példátlan erőfeszítéseinek vagyunk tanúi, aminek eredményeként számos elektronikus (számítógépes vagy mobiltelefonon használható), látássérült személyeket segítő rendszert és szoftvert fejlesztettek ki, melyek segítik a mobilitást (Cutter \& Manduchi, 2013), a tárgyfelismerést (Gallo \& Manduchi, 2011) és a navigációt (Vera, Zenteno, \& Salas, 2013). 


\section{A vakvezetőkutyák felkészítésének és alkalmazásának rövid bemutatása}

A sérült személyek életében fontos szerepet játszhat egy segítőkutya az önálló életvitelben, az egyenlő hozzáféréshez való jog gyakorlásában, ezen felül akár a mindennapi veszélyek elhárításában is, emellett habilitációs és rehabilitációs feladatokat láthat el (1998. évi XXVI. törvény; 27/2009. [XII. 3.] rendelet). A segítőkutyák kiképzése a vakvezetőkutyák képzésével kezdődött a II. világháború után. A közelmúltban a segítőkutyák köre kibővült, hiszen most már ismerünk többek között rohamot és hangot jelző kutyát, autista gyermekeket segítő kutyát és mozgáskorlátozott személyt segítő kutyát (Stace, 2016).

A segítőkutyák alkalmazhatóságuk szerinti osztályozása hazai viszonylatban a következő:

a) vakvezetőkutya: a látássérült személy vezetésére kiképzett kutya;

b) mozgáskorlátozott személyt segítő kutya: a mozgáskorlátozott személyt mindennapi tevékenységeinek ellátásában segítő feladatokra kiképzett kutya;

c) hangot jelző kutya: a hallássérült személy számára veszélyt vagy egyéb fontos információt jelentő hangok jelzésére kiképzett kutya;

d) rohamjelző kutya: az epilepsziával élő személy vagy más krónikus, rohamszerú állapotoktól veszélyeztetett személy számára a roham során segítséget nyújtó feladatokra kiképzett kutya;

e) személyi segítő kutya: a fogyatékos személyt önálló életvitelében segítő feladatokra kiképzett kutya;

f) terápiás kutya: a gyógypedagógiai, pszichológiai, pszichiátriai, konduktív pedagógiai habilitációs, illetve rehabilitációs folyamatban alkalmazott kutya (1998. évi XXVI. törvény; 27/2009. [XII. 3.] rendelet).

A vakvezetőkutyák használata széles körben elterjedt már a múlt században. Az Egyesült Államokban a kutyakiképző iskolák nagy részét az I. és a II. világháború között alapították. A XX. században a németjuhász kutya nagy sikernek örvendett, ennek következtében ezt a fajtát választották leggyakrabban vakvezetőkutyának (Bonneau, 2000). Az utóbbi években a labrador retriever és a golden retriever fajták iránt nőtt meg az érdeklődés (Alterisio és mtsai, 2019).

A vakvezetőkutyák segítik gazdáikat az önálló és biztonságos tájékozódásban és közlekedésben, több függetlenséget, szabadságot adva nekik. A vakvezetőkutyák segítséget nyújtanak a látássérült személyeknek a helyek, helyszínek megtalálásában, az akadályok kikerülésében, megkönnyítik a vak vagy gyengénlátó személyek számára a tömegközlekedés használatát, a bevásárlóközpontokban és az épületekben való navigációt, az ajtók és ülések megtalálását (Assistance Dogs International, 2020).

Hosszú képzési időre van szükség ahhoz, hogy képesített vakvezetőkutya váljon egy tanítványból. A vakvezetőkutyákat arra képzik ki, hogy segítsék a mobilitást azáltal, hogy gazdáikat az akadályokat kikerülve vezetik (Naderi, Miklósi, Dóka, \& Csányi, 2001), így közvetlenül növelik a mobilitás hatékonyságát és megakadályozzák a sérüléseket.

A vakvezetőkutya használata számos egyedi előnyt kínál, beleértve a fokozott függetlenséget, magabiztosságot, mobilitást, társadalmi interakciókat (Whitmarsh, 2005), és lehetővé teszi a tulajdonos számára, hogy teljes és aktív életet éljen. Azok a látássérült személyek, akik rendelkeznek vakvezetőkutyával, általában úgy találják, hogy életminőségük javul az extra biztonság, a fokozott függetlenség, valamint az intelligens és motivált kutyák nyújtotta biztonság révén. A közvélemény magasra értékeli a kutyákat, így akik vakvezetőkutyával közlekednek, gyakran arról számolnak be, 
hogy társadalmi interakcióik száma növekedett (Bonneau, 2000). Egy később megjelent tanulmány azonban cáfolja ezeket az állításokat. Eszerint a vakvezetőkutya jelenléte nem társult jobb életminőséggel (Glenk, Přibylová, Stetina, Demirel, \& Weissenbacher, 2019). McIver, Hall és Mills (2020) tanulmánya szembe megy ezzel az állítással, eredményeik alapján a vakvezetőkutyát használó személyek az idő múlásával életminőségbeli javulást, növekedést mutatnak. A gazdák arról számoltak be, hogy a vakvezető kutyák a látássérült személyeket sétára ösztönzik (Yamamoto, Yamamoto, \& Hart, 2015). A látássérült emberek fizikai aktivitása gyakran alacsony vagy teljesen hiányzik, de mivel fontos a vakvezetőkutyával közlekedő személyeknek, hogy optimális élményeket kínáljanak kutyáiknak, így motivációt kapnak a gyalogláshoz, ezáltal fizikai aktivitásuk növekedhet.

\section{Kutatási célok a szakirodalmi áttekintés tükrében}

Papadopoulos (2014) kutatása azt mondja, hogy közvetlen kapcsolat van a belső kontrollhely és a globális önértékelés között. Azok a látássérült felnőttek, akik képesek önállóan közlekedni, nagyrészt belső kontrolhellyel rendelkeznek. Így kapcsolatba hozható a kontrollhely a tájékozódással és közlekedéssel, ezáltal a tájékozódás és közlekedés képessége közvetett kapcsolatba hozható a globális önértékeléssel.

Az önálló mobilitás vizsgálata során a látássérült személyek esetében érdemes azt is figyelembe venni, hogy a gyengénlátó egyének elutasítják, vagy nem profitálnak a vak személyek által preferált alkalmazkodási magatartásból és készségekből, így a közlekedés során használt kompenzációs lehetőségeket és segédeszközöket sem használják megfelelőképpen. Ezek a személyek gyakran segédeszköz és látó segítség nélkül közlekednek. Ennek eredményeként nem feltétlenül tudnak teljesen önállóan élni, rosszul definiált önkoncepcióval rendelkezhetnek és társadalmilag kellemetlen helyzeteket élhetnek át (Tuttle \& Tuttle, 2004).

A fenti megállapításokból kiindulva, jelen felmérésünkben a közlekedés során használt kompenzációs/támogatási lehetőségek mentén vizsgáljuk meg a látássérült felnőttek önértékelését.

\section{Hipotézisek}

1. A vakvezetőkutyával közlekedő látássérült személyek önértékelése magasabb, mint a látóvezetővel vagy eszköz nélkül közlekedő látássérült személyeké.

2. Azok a vizsgálatban résztvevő látássérült személyek, akik a közlekedés során legtöbbször segédeszközt használnak, nagyobb önértékeléssel rendelkeznek, mint akik legtöbbször segédeszköz-használat helyett látóvezetôvel, vagy segédeszköz/támogatás nélkül közlekednek.

\section{MódsZer}

\section{A kutatás résztvevői}

Kutatásunkba 93 látássérült felnőttet vontunk be. A résztvevők 62,4\%-a (n=58) nő. A minta 37,6 \%-a ( $\mathrm{n}=35)$ férfi. Az átlag életkor 42 év, a legfiatalabb résztvevő 18 éves, míg a legidősebb 79 éves.

Az elsődleges közlekedési formák/szokások mentén a résztvevők eloszlása a következő: 14\%uk vakvezetőkutyával közlekedik ( $\mathrm{n}=13$ ), fehér bottal 39,8\%-uk ( $\mathrm{n}=37$ ) közlekedik, látóvezető segítségével 16,1\%-uk (n=15), míg segédeszköz/támogatás nélkül a megkérdezettek 30\%-a (n=28) 
közlekedik. A látássérülés megjelenésének időpontját tekintve a résztvevők 58,1\%-a ( $\mathrm{n}=54$ ) veleszületetten, míg 41,9\%-a (n=39) a szerzetten látássérült személy.

A segédeszköz/támogatás nélkül közlekedő személyek közlekedési szokásait részleteseben nem tanulmányoztuk, arra a felmérés során alkalmazott kérdések nem tértek ki. Az elsődlegesen segédeszközzel közlekedő résztvevők a felmérés alapján fehér botot használnak.

A kutatás online platformon folyt. A vizsgálatba tapasztalati szakértőt vontunk be, hogy a kérdőívet a látássérült személyek által használt online felületeken keresztül könnyen eljuttathassuk minél több felnőtt látássérült személyhez. A kérdőívet a kerdoiv.hu programmal szerkesztettük meg, amely adatvédelmi és akadálymentesítési szempontból is megfelelőnek bizonyult. A látássérült személyek számára is könnyen kitölthető volt a kérdőív, mivel az oldal lehetővé tette, hogy a szerkesztése során beállítható legyen a nagyobb méret, valamint a kellően kontúros és kontrasztos vizuális megjelenítés. A kérdőív képernyőolvasó szoftverekkel is könnyen kitölthető volt.

\section{Mintavételi eljárás}

A kutatás során hólabda mintavételi módszert alkalmaztunk. Ez a módszer egy nem valószínúségi mintavétel, ami a nehezen hozzáférhető populációk esetében alkalmazható. Ebben az esetben egy vizsgált személyen keresztül jutunk el a következő résztvevőhöz, azon keresztül az azt követőhöz és így tovább (Szokolszky, 2004). A hólabda mintavétel a kutatás erőforrásainak szempontjából költséghatékony volt, viszont így a minta nem reprezentatív a Magyarországon élő látássérült felnőtt populációra nézve.

A kutatásunkban az úgynevezett ,informátorok” a tapasztalati szakértők voltak, akik nem csak továbbították a kérdőívünket, hanem maguk is kitöltötték, így ők is kutatásunk résztvevőivé váltak. A tapasztalati szakértők olyan online csoportok tagjai, melyekhez nekünk nincs hozzáférésünk, így általuk jutott el a kutatás eszköze, a Rosenberg Önértékelés Skála az adott populációhoz.

\section{A kutatásban használt eszköz}

A kutatásunkban használt eszköz a Rosenberg Önértékelés Skála. „Az önértékelés mérésére több, önbeszámolón alapuló kérdőívet kifejlesztettek, ezek közül az 1965-ben publikált Rosenberg Önértékelés Skála (Rosenberg Self-esteem Scale - RSES; Rosenberg, 1965) az egyik leggyakrabban használt és legtöbb nyelvre lefordított mérőeszköz." (Sallay, Martos, Földvári, Szabó, \& Ittzés 2014, p. 261).

Egy négyfokozatú Likert-skála segítségével (1 - Egyáltalán nem értek egyet, 2 - Nem értek egyet, 3 - Egyetértek, 4 - Teljesen egyetértek) jelölheti meg a kitöltő személy, hogy mennyire ért egyet az adott állítással. A skála megbízhatóságát és érvényességét több vizsgálati mintán bizonyították (pl. serdülők, idősek,). Különböző kultúrákban kapott kutatási eredmények igazolják a skála érvényességét, megbízhatóságát (Kiss, 2009). Magyarországon több fordítása is megjelent, így magyar nyelvű adaptált formában is jelen van a szakirodalmakban (pl. Kiss, 2009; Sallay és mtsai, 2014). Rosenberg elképzelése szerint az önértékelés egydimenziós konstruktum, és a kérdőívet is egydimenziós mérőeszköznek szánta, amelynek 10 tétele van, ezek mérik a személy negatív és 
pozitív attitűdjét is saját magával szemben. A 10 tétel közül 5 pozitívan és 5 negatívan megfogalmazott állítás, de ugyanazt a pszichológiai konstruktumot méri (Sallay és mtsai, 2014).

A skála által kapott adatokat elemeztük, a statisztikai vizsgálat az SPSS programmal történt (egytényezős varianciaanalízis, és Mann-Whitney U teszt).

\section{EREDMÉNYEK}

Első hipotézisünk vizsgálatánál elsőként a vakvezetőkutyával közlekedő személyek önértékelését vetettük össze a látóvezetővel közlekedők önértékelésével, majd az segédeszköz/támogatás nélkül közlekedőkével, végül pedig a segédeszközzel közlekedő látássérült személyek önértékelésével. A vakvezetőkutyával közlekedő személyek csoportjának önértékelését vizsgálva az eredmények szignifikáns különbséget nem mutattak $(\mathrm{p}>, 05)$ a csoportok között. Tehát vakvezetőkutyával közlekedő személyek önértékelése szignifikánsan nem tér el azon személyek önértékelésétől, akik elsődlegesen látóvezetővel, eszköz nélkül vagy segédeszközzel közlekednek.

Az alábbi diagram a vizsgált csoportok önértékelési pontszámainak átlagait jeleníti meg. A vizuális analízist megfigyelve fellelhető némi különbség az egyes csoportok önértékelési pontszámainak átlagai között, azonban ezek nem szignifikáns eredmények. (lásd 1 ábra).

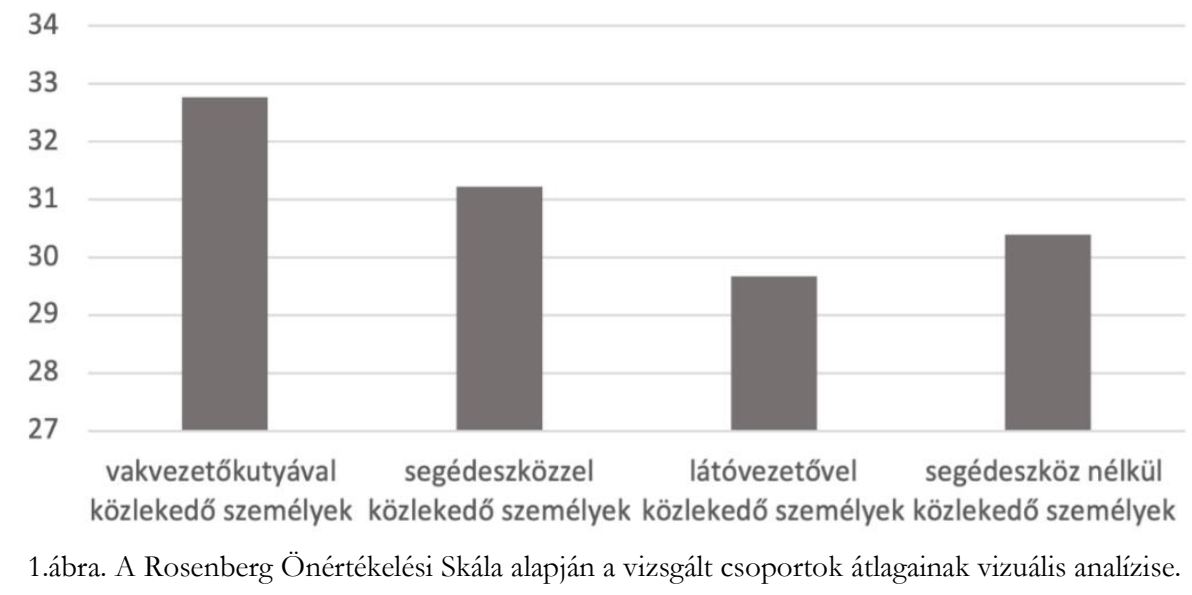

Összevontuk a látóvezetővel közlekedő személyek és a segédeszköz nélkül közlekedők csoportját, majd az önértékelés mentén összehasonlítottuk, azokkal a személyekkel, akik vakvezetőkutyával közlekednek. A Mann-Whitney próba rangsorolási technikáján kívül nincs más alkalmas teszt, ami ekkora különbségnél hatékonyan össze tudná vetni a vizsgálatban megjelenő mintákat. Az eredményeket tekintve nincs szignifikáns különbség ( $\mathrm{p}>, 05)$.

A próbák eredményeit összegezve nincs eltérés a vakvezetőkutyával közlekedő személyek önértékelése és azon személyek önértékelése között, akik látóvezetôvel, illetve akik segédeszköz nélkül közlekednek.

Az eredmények alapján (2. ábra) elmondható, hogy a vakvezetőkutyával közlekedő látássérült személyek önértékelésére vonatkozó egyesített rangátlag $(M R=34,692)$ magasabb, mint azoknak a 
személyeknek az egyesített rangátlaga (MR=26,628), akik látóvezetôvel, vagy segítség nélkül közlekednek.

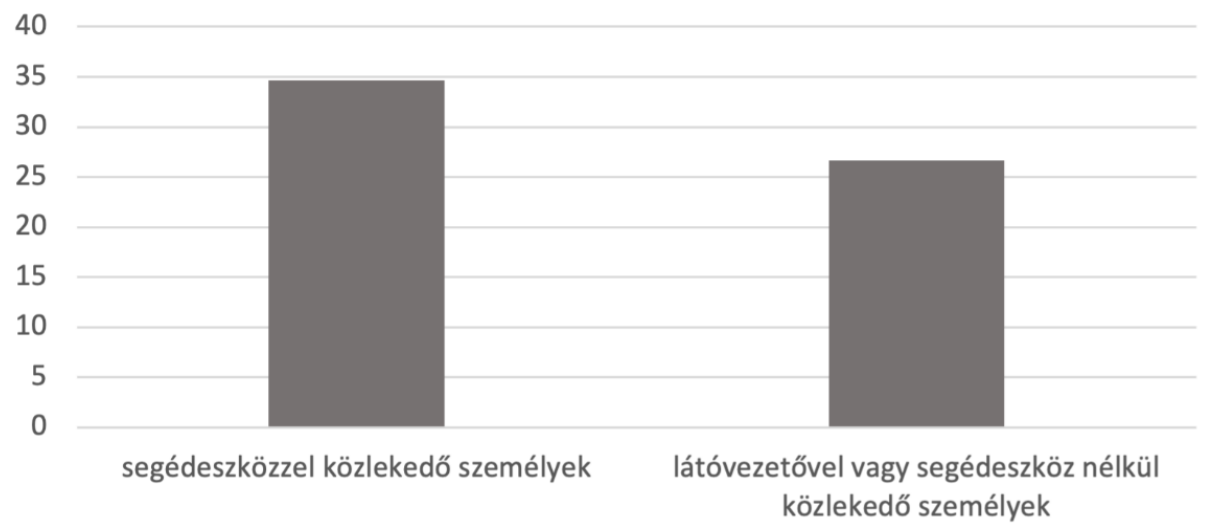

2. ábra. A vizsgált csoportok vizuális analízise.

Az első hipotézisünkben azt állítottuk, hogy a vakvezetőkutyával közlekedő látássérült személyek önértékelése magasabb, mint azoké, akik látóvezetővel vagy eszköz nélkül közlekednek. A hipotézisünk nem igazolódott be a kutatásban résztvevő személyek esetében a vizsgált változó mentén, vagyis az önértékelést vizsgálva nem volt szignifikáns különbség a csoportok között. A csoportokat mi határoztuk meg a vizsgált minták közlekedési szokásait alapul véve, majd hasonlítottuk össze őket. A csoportosítás során nem volt más változó, ami befolyásolta volna a csoportok kialakítását, mint például az életkor vagy a látásteljesítmény.

Az elemzések során végzett vizuális analíziseknél kisebb mértékű különbségek láthatóak az egyes csoportok önértékelési pontszámai között, azonban ezek nem szignifikáns eredmények.

A második hipotézisünkhöz tartozó adatok feldolgozásához az összehasonlító eszközök közül az ANOVA próbát használtuk. A vizsgálni kívánt három csoportra nézve, vagyis a segédeszközzel, a látóvezetővel, és a segédeszköz/támogatás nélkül közlekedő személyek csoportját tekintve az ANOVA próba alkalmazásához szükséges feltételek teljesültek. A normál eloszlás vizsgálatára a Kolmogorov-Szmirnov-próbát alkalmaztuk, melynek eredménye nem szignifikáns ( $p=$ =085), míg a szórás egyenlőtlenségének ellenőrzéséhez a Levene-tesztet használtuk. A Levene-próba nem szignifikáns, így a szórásegyezés feltétele teljesül $(\mathrm{F}(2,175)=2,515 ; \mathrm{p}=0,08)$. Az eredmények értelmében az ANOVA alkalmazásához szükséges feltételek teljesültek a vizsgált csoportok esetében.

Az ANOVA alapján megállapítható, hogy a csoportok között nincs szignifikánsan különbség $(\mathrm{F}(2,175)=0,383 ; \mathrm{p}>, 05)$.

A második hipotézisünkben azt állítottuk, hogy azok a vizsgálatban résztvevő látássérült személyek, akik a közlekedés során legtöbbször segédeszközt használnak, nagyobb önértékeléssel rendelkeznek, mint akik legtöbbször segédeszköz használat helyett látóvezetôvel, vagy segédeszköz/támogatás nélkül közlekednek. A hipotézisünk nem igazolódott be az általunk vizsgált minta esetében, az önértékelést tekintve nem volt szignifikáns különbség a csoportok között.

A következőkben két mintát hasonlítottunk össze. Az előző vizsgálat során két különálló csoportként vizsgáltuk azokat a személyeket, akik látóvezetôvel, és azokat, akik segédeszköz nélkül közlekednek, azonban a Mann-Whitney próbánál összevontuk őket. Az így kapott mintát összehasonlítottuk azokkal a látássérült személyekkel, akik segédeszközt használnak. 
A Mann-Whitney próba eredményeit tekintve nincs szignifikáns különbség $(\mathrm{p}>, 05)$ a segédeszközzel közlekedők és azon személyek önértékelése között, akik látóvezetővel vagy segédeszköz nélkül közlekednek.

Az egyesített rangsorszám tekintetében látható némi különbség (lásd 3. ábra). Magasabb érték figyelhető meg a segédeszközzel közlekedő látássérült személyek önértékelésénél, ahol a rangátlag MR=43,108, mint azoknál a személyeknél, akik látóvezetővel, vagy eszköz nélkül közlekednek $\mathrm{MR}=38,256$.

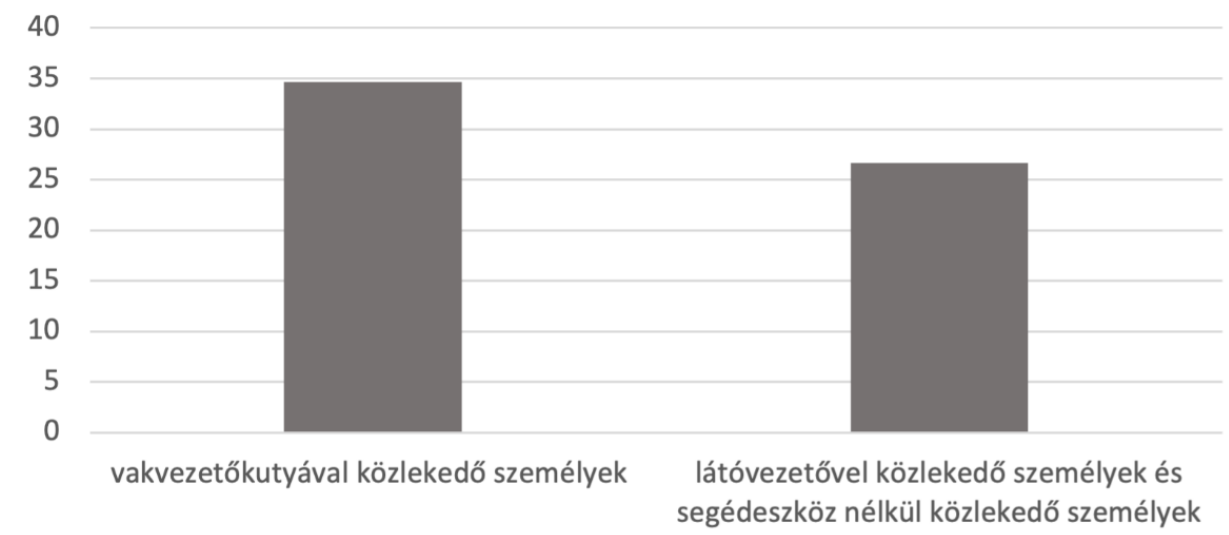

3. ábra. A vizsgált csoportok vizuális analízise.

Azt állítottuk, hogy azok a vizsgálatban résztvevő látássérült személyek, akik a közlekedés során legtöbbször segédeszközt használnak, nagyobb önértékeléssel rendelkeznek, mint akik legtöbbször segédeszköz használat helyett látóvezetővel, vagy segédeszköz/támogatás nélkül közlekednek. A hipotézisünk nem igazolódott be az általunk vizsgált minta esetében, az önértékelést tekintve nem volt szignifikáns különbség a csoportok között.

Az eredmények ismertetése során bemutattuk, hogy a vakvezetőkutyával és segédeszközzel közlekedő, vizsgálatba bevont személyek nagyobb átlag önértékelési pontszámmal rendelkeznek, mint azok a személyek, akik látóvezetővel és segítség nélkül közlekednek. Azonban ezeket a számítások nem támasztották alá.

Két csoportra osztottuk a mintát veleszületetten és a szerzetten látássérült személyekre. A két csoportban résztvevők önértékelését Mann- Mann-Whitney próbával hasonlítottuk össze, az eredmények nem mutattak szignifikáns különbséget ( $\mathrm{p}>, 05)$. Ezt követően külön-külön vizsgáltuk a két csoport önértékelését az elsődleges közlekedési formák mentén.

A veleszületetten látássérült személyek csoportjában az önértékelési pontok legalacsonyabb értéke 15, míg a legmagasabb 40, az átlag $\mathrm{M}=31,3$ és a szórás $\mathrm{SD}=5,55$.

A veleszületetten látássérült személyek önértékelését a közlekedési formák mentén vizsgáltuk ANOVA próbával, mely nem mutatott szignifikáns különbséget ( $\mathrm{p}>, 05)$ a csoportok között.

Hasonló vizsgálatot végeztünk a szerzetten látássérült személyek csoportjánál is. A legalacsonyabb érték itt 17, míg a legmagasabb, vagyis a felsőhatár 40, az átlag M=30,3 és a szórás $\mathrm{SD}=6,1$. Ebben az esetben is a közlekedési formák mentén vizsgáltuk az önértékelést és ANOVA- 
t használtunk az elemzések során. Az eredmények alapján a csoportok között nem volt szignifikáns különbség $(\mathrm{p}>, 05)$.

Összegezve az előbbi eredményeket, beemeltük a látáscsökkenés/látásvesztés bekövetkeztének idejét, majd a szerzetten és veleszületetten látássérült személyeket külön csoportra osztottuk, és ezt követően vizsgáltuk meg ismét a résztvevők önértékelését az elsődleges közlekedési forma mentén. A vizsgálatok ez esetben sem mutattak szignifikáns különbséget a csoportok között.

\section{KÖVETKEZTETÉS}

Papadopoulos (2014) eredményeiből kiindulva, azokra építkezve fogalmazódtak meg a kutatás alapfeltevései. Az említett kutatás bizonyította, hogy kapcsolat van a magas önértékelés és a belső kontrollhely között, illetve, hogy azok a látássérült személyek, akik önállóan közlekednek, belső kontrollhellyel rendelkeznek. Közvetve ugyan, de kapcsolatba lehet hozni a látássérült személyek önértékelését az önálló mozgással, sőt globálisan tekintve még a tájékozódási és közlekedési képességgel is.

A globális önértékelés a jóllét és a mentális egészség egyik mutatója, így az adott személy életminőségét is nagymértékben befolyásolhatja (Rosenberg és mtsai, 1995). McIver és munkatársai (2020) szerint a vakvezetőkutyával közlekedő látássérült személyek életminősége az idő múlásával javul.

Az előzőekben említett kutatásokra alapozva fogalmaztuk meg feltevéseinket. A tanulmányban szereplő hipotetikus állítások által arra próbáltunk rájönni, hogy a látássérült személyek önértékelésére milyen hatással van az adott személy által használt elsődleges közlekedési forma. A vizsgált minta esetében az elsődleges közlekedési formák mentén nincs különbség a látássérült személyek önértékelését tekintve. Ennek értelmében a látássérült személyek önértékelése és a személy által választott (elsődleges) közlekedési forma között nincs együttjárás.

Papadopoulos, Montgomery és Chronopoulou (2013) kutatása rávilágított, hogy a látássérült személyeket bizonyos kritériumok alapján érdemes csoportosítani, ha az önértékelés mentén szeretnénk vizsgálni az adott személyeket. Papadopoulos (2014) kutatása szerint a szerzetten látássérült személyeknek alacsonyabb az önértékelésük, mint a veleszületetten látássérült személyeknek. Ebből kiindulva a résztvevők önértékelését úgy vizsgáltuk az elsődleges közlekedési formák mentén, hogy külön csoportokra osztottuk a vizsgálatban résztvevő személyeket aszerint, hogy veleszületett vagy szerzett látássérülésük van.

A vizsgálat során azt is megvizsgáltuk, hogy van-e különbség a két csoport között az önértékelést tekintve, vagyis azon személyek között, akiknek veleszületett, és akiknek szerzett látássérülésük van. Ebben az esetben nem találtunk szignifikáns különbséget. Papadopoulos (2014) tanulmányának ellentmondanak a jelen kutatás eredményei. Azonban torzító tényezőként megjelenhet a látássérülés bekövetkeztének időpontja, így az előbb említett csoportokat külön is tanulmányoztuk, ami megerősítette a jelen vizsgálat eddigi következtetéseit.

Az eredmények arra utalnak, hogy az elsődleges közlekedési formák esetében nem lehet meghatározni egy mindenki számára ideális kategóriát, amely minden látássérült személynek hasonló mértékben megfelelne. 
Összegezve: a rehabilitációs munka során nagy hangsúlyt kell fektetni arra, hogy a látássérült személyek megtalálják azt az elsődleges közlekedési formát, amely számukra komfortos, biztonságos, és amellyel sikeresebbnek élik meg a mindennapjaikat.

\section{A kutatás korlátai}

Az online felületeken csak bizonyos számú látássérült személyhez tudott eljutni kérdőívünk. Így nem kaptunk átfogó eredményeket a vizsgálatban megjelenő hipotetikus állításokkal kapcsolatban.

Fontos megemlíteni, hogy a kategóriák, amelyek szerint a résztvevőket felosztottuk, és amelyek mentén önértékelésüket vizsgáltuk, ritka esetben különíthetők el szigorúan egymástól, mivel a vizsgált személyek több közlekedési formát is használnak, használhatnak a felsoroltak közül. Mivel csak elsődleges közlekedési formákról beszéltünk, ezt torzíthatja az eredményeket.

\section{A vizsgálat folytatásának lehetőségei}

A fókuszban lévő populáció sajátosságait figyelembe véve, érdemes lenne néhány változtatást beiktatva tovább tanulmányozni a témakört. A látássérült felnőttek esetében a látássérülés súlyossági foka is befolyásoló tényező lehet, ha az elsődleges közlekedési mód mentén szeretnénk vizsgálni az önértékelést. Roy és MacKay (2002) kutatása alapján a vak személyek magasabb önértékeléssel rendelkeznek, mint a gyengénlátó fiatal felnőttek. Egy később megjelent kutatásban Papadopoulos (2014) hasonló eredményekről számolt be, így megerősítve az előző kutatás eredményeit.

A látássérült személyek önértékelését befolyásoló tényezők között helyet kaphat még az iskolai végzettség és a vizsgált személyek neme. Az iskolai végzettség az önbecsülés egyik előrejelzője, mivel az alacsonyabb iskolai végzettségú személyek alacsonyabb önértékelési pontszámot mutatnak (Papadopoulos 2014). Augestad (2017) tanulmánya szerint a látássérült lányok önbecsülése alacsonyabb, mint a látássérült fiúké. Nincs egyetértés e tekintetben a kutatók között, azonban az előbb említett tanulmány több kutatást összehasonlított és így jutott erre a következtetésre.

Összegezve, az ajánlott változtatások mentén érdemes lenne tovább vizsgálni a témával kapcsolatos felvetéseket.

\section{IRODALOMJEGYZÉK}

Alterisio, A., Scandurra, A., Eatherington, C. J., Marinelli, L., D'Aniello, B., \& Mongillo, P. (2019). You can't see, when I do: A study on social attention in guide dogs. Applied Animal Behaviour Science, 218.,104824, ISSN 0168-1591.

Assistance Dogs International (2020). ADI Terms \& Definitions. Letöltve: 2020.11.01. https://assistancedogsinternational.org/

Augestad, L. B. (2017). Self-concept and self-esteem among children and young adults with visual impairment: A systematic review. Cogent Psychology, 4(1), DOI: $\underline{10.1080 / 23311908.2017 .1319652}$ 
Baumeister Baumeister, R. F., Campbell, J. D., Krueger, J. I., \& Vohs, K. D. (2003). Does high self-esteem cause better performance, interpersonal success, happiness, or healthier lifestyles? Psychological Science in the Public Interest, 4(1), 1-44. https://doi.org/10.1111/1529-1006.01431

Baumeister, R. F., \& Tice, D. M. (1985). Self-esteem and responses to success and failure: Subsequent performance and intrinsic motivation. Journal of Personality, 53(3), 450-467. https://doi.org/10.1111/i.1467-6494.1985.tb00376.x

Bonneau, L. (2000). Compensating for sight loss with a guide dog. Insight - the Journal of the American Society of Ophthalmic Registered Nurses, 25(4), 125-127. DOI: 10.1067/min.2000.109457

Bowen, J. (2010). Visual impairment and its impact on self-esteem. British Journal of Visual Impairment, 28.(19), 47-56 https://doi.org/10.1177/0264619609349429

Branch, L. G., Horowitz, A., \& Carr, C. (1989). The implications for everyday life of incident self-reported visual decline among people over age 65 living in the community. Gerontologist, 29(3), 359-365. DOI: $10.1093 /$ geront/29.3.359

Cardinali, G., \& D’Allura, T. (2001). Parenting styles and self-esteem: A study of young adults with visual impairments. Journal of Visual Impairment and Blindness, 95(5), 261-271. https://doi.org/10.1177/0145482X0109500502

Clark-Carter, D. D., Heyes, A. D., \& Howarth, C. I. (1986). The efficiency and walking speed of visually impaired people. Ergonomics, 29(6), 779-789. https://doi.org/10.1080/00140138608968314

Cutter, M., \& Manduchi, R. (2013). Real Time Camera Phone Guidance for Compliant Document Image Acquisition without Sight. 2013 12th International Conference on Document Analysis and Recognition, 408412. DOI: $10.1109 /$ ICDAR.2013.89

Datta, P., \& Talukdar, J. (2016). The impact of vision impairment on students' self-concept. International Journal of Inclusive Education, 20, 659-672. https://doi.org/10.1080/13603116.2015.1111441

Dávid A., Gadó M., \& Csákvári J. (2008). Látássérïlt emberek elemi és foglalko oásirehabilitációja. FSZK, Budapest.

Dodds, A. (1993). Rehabilitating blind and visually impaired people: A psychological approach. Chapman \& Hall, London. ISBN: 978-0-412-46970-1, https://doi.org/10.1007/978-1-4899-4461-0

Fallah, N., Apostolopoulos, I., Bekris, K., \& Folmer, E. (2013). Indoor human navigation systems: A survey. Interacting with Computers, 25(1), 21-33. https://doi.org/10.1093/iwc/iws010

Gallo, O., \& Manduchi, R. (2011). Reading 1D Barcodes with Mobile Phones Using Deformable Templates. IEEE Transactions on Pattern Analysis and Macbine Intelligence, 33(9), 1834-1843. DOI: 10.1109/TPAMI.2010.229

Glenk, L. M., Prribylová, L., Stetina, B. U., Demirel, S., \& Weissenbacher, K. (2019). Perceptions on Health Benefits of Guide Dog Ownership in an Austrian Population of Blind People with and without a Guide Dog. Animals: an open access journal from MDPI, 9(7), 428. DOI: 10.3390/ani9070428

Guerra, N. G., \& Bradshaw, C. P. (2008). Linking the prevention of problem behaviors and positive youth development: core competencies for positive youth development and risk prevention. New Directions for Child and Adolescent Development, 122, 1-17. DOI: $\underline{10.1002 / \mathrm{cd} .225}$

Guimares, C. S. S., Henriques, R. V. B., \& Pereira, C. E. (2016). Tracking System Proposal of Walking Sticks Aiming the Orientation and Mobility of the Visually Impaired. IFAC-PapersOnLine, 49(30), 161-166. https://doi.org/10.1016/j.ifacol.2016.11.147

Harter, S. (1999). The construction of the self: a developmental perspective. Guilford Press, New York. ISBN-13: 9781572304321.

Harter, S. (2006). The self. In N. Eisenberg, R. M. Lerner, \& W. Damon (Eds.). Handbook of cbild psychology: Social, emotional, and personality development. (pp. 505-570). John Wiley \& Sons, Hoboken.

Huurre, T. M., Komulainen, E. J., \& Aro, H. M. (1999). Social support and self-esteem among adolescents with visual impairments. Journal of V isual Impairment and Blindness, 93(1), 26-37. ISSN: ISSN-0145-482X. 
Kiss P. (2009). Önértékelés, elégedettség, identitás személyes és társadalmi vetületei. In Kiss P. (szerk.). Emberi kapcsolatok és társadalmi nézetek. kérdốiv skáláinak megbiz̧hatósági és érvényességi vizsgálata. Eötvös Kiadó, Budapest.

MacDonald, G., Saltzman, J. L., \& Leary, M. R. (2003). Social approval and trait self-esteem. Journal of Research in Personality, 37(2), 23-40. https://doi.org/10.1016/S0092-6566(02)00531-7

Marsh, H. W. (1990). A multidimensional, hierarchical model of self-concept: theoretical and empirical justification. Educational Psychology Review, 2, 77-172. https://doi.org/10.1007/BF01322177

Marsh, H. W., \& Shavelson, R. (1985). Self-concept: its Multifaceted, hierarchical structure. Educational Psychologist, 20(3), 107-123. https://doi.org/10.1207/s15326985ep2003 1

McIver, S., Hall, S., \& Mills D. S. (2020). The Impact of Owning a Guide Dog on Owners' Quality of Life: A Longitudinal Study. Anthrozoös, 33(1), 103-117. https://doi.org/10.1080/08927936.2020.1694315

Mishra, V., \& Singh, A. (2012). A comparative study of selfconcept and self-confidence of sighted and visually impaired children. Excel International Journal of Multidisciplinary Management Studies, 2, 148-156

Naderi Sz., Miklósi Á., Dóka A., \& Csányi V. (2001). Co-operative interactions between blind persons and their dogs. Applied Animal Behaviour Science, 74(1), 59-80. https://doi.org/10.1016/S0168$\underline{1591(01) 00152-6}$

Neal, J., Bigby, L., \& Nicholson, R. (2004). Occupational therapy, physical therapy, and orientation and mobility services in public schools. Intervention in School and Clinic, 39(4), 218-222. ISSN: ISSN-1053-4512

Pálhegyi F. (1981). A látás nélkëil meghódított világ. MVGYOSZ, Budapest.

Papadopoulos, K. (2014). The impact of individual characteristics in self-esteem and locus of control of young adults with visual impairments. Research in Developmental Disabilities, 35(3), 671-675. https://doi.org/10.1016/i.ridd.2013.12.009

Papadopoulos, K., Montgomery, A. J., \& Chronopoulou, E. (2013). The impact of visual impairments in selfesteem and locus of control. Research in Developmental Disabilities, 34(12), 4565-4570. https://doi.org/10.1016/j.ridd.2013.09.036

Richter, A., \& Ridout, N. (2011). Self-esteem moderates affective reactions to briefly presented emotional faces. Journal of Research in Personality, 45(3), 328-331. https://doi.org/10.1016/i.jrp.2011.02.008

Rosenberg, M. (1965). Society and the adolescent self-image. Princeton University Press, Princeton.

Rosenberg, M., Schooler, C., Schoenbach, C., \& Rosenberg, F. (1995). Global self-esteem and specific selfesteem: Different concepts, different outcomes. American Sociological Review, 60(1), 141-156. https://doi.org/10.2307/2096350

Roy, W. N., \& MacKay, G. F. (2002). Self-perception and locus of control in visually college students with different types of vision loss. Journal of Visual Impairment \& Blindness, 96(4), 254-266. https://doi.org/10.1177\%2F0145482X0209600407

Saadat, M., Ghasemzadeh, A., Karami, S., \& Soleimani, M. (2012). Relationship between self-esteem and locus of control in Iranian University students. Procedia - Social and Behavioral Sciences, 31, 530-535. https://doi.org/10.1016/j.sbspro.2011.12.099

Sallay V., Martos T., Földvári M., Szabó T., \& Ittzés A. (2014). A Rosenberg Önértékelés Skála (RSES-H): alternatív fordítás, strukturális invariancia és validitás. Mentálbigiéné és Psæichoszomatika, 3, 259-275. https://doi.org/10.1556/mental.15.2014.3.7

Stace, L. B. (2016). Welcoming max: Increasing pediatric provider knowledge of service dogs. Complementary Therapies in Clinical Practice, 24, 57-66. https://doi.org/10.1016/i.ctcp.2016.05.005

Strumillo, P. (2010). Electronic interfaces aiding the visually impaired in environmental access, mobility and navigation. In $3 \mathrm{rd}$ International Conference on Human System Interaction (pp. 17-24). IEEE. https://doi.org/10.1109/HSI.2010.5514595

Tuttle, D. W., \& Tuttle, N. R. (2004). Self-esteem and adjusting with blindness (3rd ed.). Charles C Thomas, Springfield. ISBN: 0398075085. 
Vera, P., Zenteno, D., \& Salas, J. (2013). A smartphone-based virtual white cane. Pattern Analysis and Applications, 17(3), 623-632. https://doi.org/10.1007/s10044-013-0328-8

Warren, W. H. (1984). Perceiving affordances: Visual guidance of stair climbing. Journal of Experimental Psychology: Human Perception and Performance, 10(5), 683-703. https://doi.org/10.1037//0096$\underline{1523.10 .5 .683}$

Webster, A., \& Roe, J. (1998). Children with visual impairments. Routledge, London. ISBN: 0415148154. https://doi.org/10.1177\%2F026461969801600208

Were, C. H., Indoshi, F. C., \& Yalo, J. A. (2010). Gender differences in self-concept and academic achievement among visually impaired pupils in Kenya. Educational Research, 1(8), 246-252.

Whitmarsh, L. (2005). The benefits of guide dog ownership. Visual Impairment Research, 7(1), $27-42$. https://doi.org/10.1080/13882350590956439

Wortman, C. B., \& Silver, R. C. (1989). The myths of coping with loss. Journal of Consulting and Clinical Psychology, 57(3), 349-357. https://doi.org/10.1037//0022-006x.57.3.349

Yamamoto, M., Lopez, M., \& Hart, L. A. (2015). Registrations of assistance dogs in California for identification tags. PLoS One, 10(8), 1-20. https://doi.org/10.1371/journal.pone.0132820

\section{Jogi források}

1998. évi XXVI. törvény a fogyatékos személyek jogairól és esélyegyenlőségük biztosításáról. A szociális és munkaügyi miniszter 27/2009. (XII. 3.) SZMM rendelete a segít kutya kiképzésének, vizsgáztatásának és alkalmazhatóságának $\quad$ szabályairól. $\quad$ Letöltve: https://net.jogtar.hu/jogszabaly?docid=a0900027.smm

\section{Guide dogs and equipment use as factors influencing self-esteem in visually impaired individuals}

\footnotetext{
ABSTRACT

Background and goals: Global self-esteem in general is an important indicator of well-being and mental health (Rosenberg, Schooler, Schoenback, \& Rosenberg, 1995), which can be one indicator of the effectiveness of special education rehabilitation work. Considering studies of self-esteem in the visually impaired persons (Huurre, Komulainen \& Aro, 1999; Cardinali \& D’Allura, 2001; Papadopoulos, Montgomery \& Chronopoulou, 2013), there is no consensus among researchers that visually impaired individuals would have lower selfesteem than their sighted peers. Our aim was to examine the global self-esteem of visually impaired people living in Hungary along transport habits and forms.

Method: In our research, we included 93 visually impaired adults (58 women and 35 men mean age is 42 years). According to the forms/habits of transport, the participants were divided into groups - number of people with a guide $\operatorname{dog}(\mathrm{n}=13)$; number of white cane users $(n=36)$; number of people using a sighted guide $(n=15)$; number of visually impaired persons traveling without assistance and assistive device $(n=27)$. Participants completed the Rosenberg Self-Esteem Scale online. The results of the self-esteem scale were compared between the already defined groups. Differences between groups were observed during the study.

Results: Based on the results, there is no significant difference between the groups ( $\mathrm{p}>, 05)$. We found no statistically significant difference between groups in terms of self-esteem.

Conclusions: The self-esteem of the examined visually impaired persons is not directly influenced by the mode of transport chosen or acquired by the given person.
}

Keywords: self-esteem, visual impairment, transport, assistive tool/white cane, guide dog 